\title{
The assessment of new bone formation induced by unfocused extracorporeal shock wave therapy applied on pre-surgical phase of distraction osteogenesis
}

\section{Purpose}

This study aims to evaluate the effects of extracorporeal shock wave therapy applied before and/or immediately after the osteotomy on the maturation during the consolidation phase.

\section{Materials and Methods}

21 female New Zealand rabbits were used in the study. Subjects were divided randomly into three groups: Control (Distraction without ESWT), A (Distraction +ESWT After Osteotomy), AB (Distraction+ESWT After and Before Osteotomy). ESWT (500 pulses, $5 \mathrm{~Hz}, 0.19 \mathrm{~mJ} / \mathrm{mm}^{2}$ energy flux density) was applied to group $A$ and group $A B$ after 5, 12 and 19 days after osteotomy and group $A B$ only on days 7,14 and 21 before osteotomy. On the $28^{\text {th }}$ day of the consolidation period, all subjects were sacrificed. Dual-energy $x$-ray absorptiometry (DEXA) was used to determine bone mineral density $(B M D)$ and bone mineral content $(B M C)$, and stereological methods were used to determine the new bone, connective tissue and neovascularization volumes.

\section{Results}

As a result of DEXA examinations made on the $1^{\text {st }}$ and $4^{\text {th }}$ week of consolidation, there was no significant difference between groups regarding BMD and BMC values. According to the results of stereological examination, when the connective tissue and new bone tissue were evaluated, higher values were observed in $A B$ when compared to $A$, and in $A B$ and $A$ compared to the control group, but the differences are not statistically significant. There was no difference between the groups in terms of neovascularization.

\section{Conclusion}

ESWT in these parameters was not positively effective in bone maturation during consolidation when applied before osteotomy or both before and after osteotomy.

Keywords: Bone regeneration; distraction osteogenesis; dual-energy $x$-ray absorptiometry; extracorporeal shock wave therapy; organ volume

\section{Introduction}

The reconstruction of congenital deformities and large bone defects due to trauma and cysts/tumors in the oral and maxillofacial region are challenging and requires complicated surgical procedures. Grafting or orthognathic surgery methods are used in the treatment of these deformities. However, these applications cannot be fully trusted in obtaining the most ideal results $(1,2)$. Owing to its many basic advantages, distraction osteogenesis (DO) has been used successfully for many years in the treatment of deformities in the maxillofacial region $(3,4)$. The greatest advantage of DO over other surgical techniques is the simultaneous expansion of the surrounding soft tissue matrix (periost, blood vessels,

\author{
Erman Senel ${ }^{1} \mathbb{D}^{\mathrm{D}}$, \\ Enes Ozkan² (D), \\ Mehmet Cihan Bereket ${ }^{3}$ (D), \\ Mehmet Emin Onger ${ }^{4}$ (I)
}

ORCID IDs of the authors: E.S. 0000-0002-3905-3463 E.O. 0000-0002-8182-9042; C.B. 0000-0003-0578-7087; M.E.O. 0000-0001-8922-9642

'Department of Oral and Maxillofacial Surgery, Faculty of Dentistry, Pamukkale University, Denizli, Turkey

${ }^{2}$ Department of Oral and Maxillofacial Surgery, Faculty of Dentistry, Istanbul Medeniyet University, Istanbul, Turkey

${ }^{3}$ Department of Oral and Maxillofacial Surgery, Faculty of Dentistry, Ondokuz Mayis University, Samsun, Turkey

${ }^{4}$ Department of Histology and Embryology, Faculty of Medicine, Ondokuz Mayis University, Samsun, Turkey

Corresponding Author: Enes Ozkan

E-mail: drenesozkan@gmail.com

Received: 20 September 2018 Revised: 6 February 2019 Accepted: 8 February 2019

DOI: 10.26650/eor.20190041 
nerve, muscle, mucosa, gingiva, skin, etc.) during bone extension (3). Despite the advances in DO techniques and technology, serious complications can occur because of the long consolidation phase (up to six months) $(1,5)$. Pin-tract infection, fibrous union or non-union, pain, fracture of the distractor, and psychological problems are among these complications $(3,6)$. These complications can be avoided by changing the rhythm of distraction or by stimulating bone regeneration that occurs during consolidation (7).

Many biostimulatory methods (low-density ultrasound, low dose laser therapy, recombinant growth factors, etc.) to induce new bone formation in DO have been the subject of research (4,8-10). Although positive results have been reported in most of the methods used, clinical use is still not accepted (11). Extracorporeal shock wave therapy (ESWT), which is reported to induce new bone formation by increasing osteogenesis and angiogenesis in the bone recovery process, may contribute to the reduction of the treatment period by inducing consolidation-phase bone regeneration in DO (12).

Various mechanisms have been claimed to influence the osteostimulatory effect of ESWT. Many studies have shown that ESWT has this effect by triggering the expression of transcription factors, mediators, and growth hormones (1315). ESWT has also been reported to induce mesenchymal cell proliferation and differentiation, and to promote osteogenesis by stimulating osteoblasts $(12,13,15,16)$. These effects have been shown to induce open fracture healing, shorten consolidation period in $\mathrm{DO}$, and increase bone mineral density $(12,17)$. In DO, all the biostimulatory methods for accelerating the consolidation period are applied within the consolidation process. To date, no study has yet evaluated the prophylactic application of ESWT in DO prior to osteotomy. Therefore, this study aims to compare the results of ESWT before and after surgical procedure to determine the most appropriate application and to obtain the best bone healing process. The null hypothesis tested in this research is that the ESWT application does not affect the bone healing process.

\section{Materials and Methods}

\section{Laboratory animals}

Supported by the Project Management Office of Ondokuz Mayıs University with project number PYO.DIS.1904.12.007, this study received ethical approval on November 25, 2012 numbered 2011/65 from the Animal Experiments Local Ethics Committee. The experiment abided by the maintenance and use agreement of experimental animals. A total of 21 female New Zealand rabbits, 6-9 months of age and weighing approximately $2.75 \mathrm{~kg}$, were used in the study. The subjects were kept in separate cages provided with standard food and water support in a $12 \mathrm{~h}$ night/day cycle. All animals received the same distractor device and bone extension protocol. After they were identified, the subjects were randomly assigned to three groups: Control (DO without ESWT) $(n=7), A$ (ESWT applied after the latency period) $(n=7), A B$ (ESWT applied before osteotomy and after the latency period) $(n=7)$

\section{ESWT protocol}

The electrohydraulic ESWT device (Orthogold 100, MTS Medical, Konstanz, Germany) and the unfocused applicator (OP155) were used in the study. Surgical lubricant gel was applied to the skin before ESWT application. The application was made by contacting the applicator of the device with the right mandible angle (Figure 1). ESWT with 500 pulse, $5 \mathrm{~Hz}$, and $0.19 \mathrm{~mJ} / \mathrm{mm}^{2}$ energy flow intensity was applied in the $A B$ group in the first, second, and third weeks before osteotomy. For the control group, a placebo application was conducted with the applicator of the device turned off. In the $A$ and $A B$ groups, the same feature of ESWT was applied to the distraction zone at 5, 12, and 19 days after osteotomy. On the $28^{\text {th }}$ day of the consolidation period, all the rabbits were sacrificed with a high dose of sodium pentobarbitone (Pentalyn; IE Ulagay, Istanbul, Turkey).

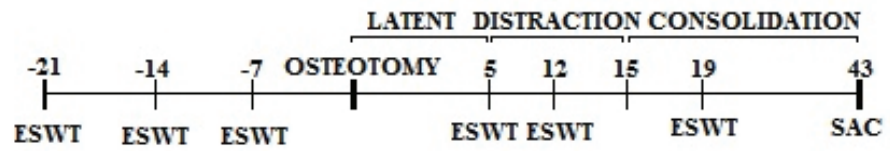

Figure 1. Timeline of experimental procedures. (SAC: Sacrification) Surgical procedure.

\section{Surgical procedure}

All subjects were starved a day before the surgery. The experimental animals were randomly selected without knowing to which group they belonged. All animals were
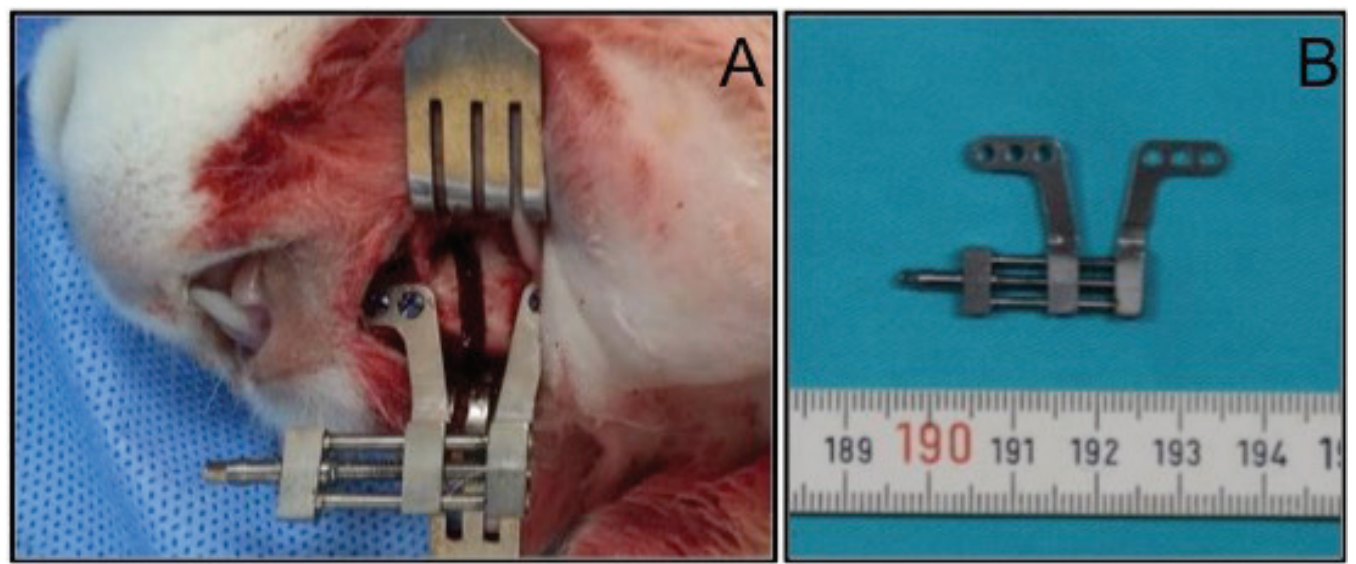

Figure 2. A. Osteotomy line is posterior to mental foramen. Distractor was adapted with six mini screw. B. The custom made titanium distractor with 6 hole can provide $10 \mathrm{~mm}$ extension. 
intramuscularly administered with $50 \mathrm{mg} / \mathrm{kg}$ ketamine $\mathrm{HCl}$ (Ketalar, Pfizer, Istanbul, Turkey) and $8 \mathrm{mg} / \mathrm{kg}$ xylazine $\mathrm{HCl}$ (Rompun, Bayer, Istanbul, Turkey) as general anesthesia. About $0.5 \mathrm{ml}$ articaine containing 1:200,000 epinephrine (Ultracain-DS; Hoechst Marion Roussel, Istanbul, Turkey) was applied as local anesthesia to the surgical site. After the mandible ramus area of the rabbits was shaved and aseptic conditions were established with iodine, a $3 \mathrm{~cm}$ linear incision was made at the inferior border of the left mandible. The bone surface was uncovered by elevating the full thickness flap. The osteotomy area passing between the first premolar tooth and the mental foramen was determined. Before osteotomy, a titanium distractor (Trimed, Electron Medical, Ankara, Turkey) was adapted parallel to the mandibular border (Figure 2A). Afterward, a bone fracture was performed with a fissure bur under sterile saline irrigation and osteotomes without causing mental nerve damage (Figure 2B). The incision area was closed up in layers with 4/0 suture (Vicryl, Ethicon, Brussels, Belgium). After a 5-day latency period, a distraction protocol was applied for 10 days at a distraction rate of $0.35 \mathrm{~mm} / 12 \mathrm{~h}$.

\section{Postoperative care}

For postsurgical pain and infection control, $1 \mathrm{mg} / \mathrm{kg}$ Tramadol (Contramal, Abdi İbrahim, Istanbul, Turkey) and 50 $\mathrm{mg} / \mathrm{kg}$ Cefazolin Sodium (Sefazol, M Nevzat, Istanbul, Turkey) were administered intramuscularly twice a day for 4 days. The animals were given a soft-food diet for a week. The weights and nutritional status of the animals were checked daily by the veterinarian.

\section{DEXA examination}

The measurements were conducted with the DEXA scanner Hologic QDR 2000, (Discovery Series, Hologic, Inc., Waltham, Mass., USA) at Ondokuz Mayıs University Faculty of Medicine, Nuclear Medicine Department, on the first and fourth weeks of consolidation under general anesthesia applied intramuscularly with 20 mg/kg ketamine HCL (Ketalar, Pfizer, Istanbul, Turkey) and $5 \mathrm{mg} / \mathrm{kg}$ xylazine HCL (Rompun, Bayer, Istanbul, Turkey). The DEXA measurements were taken by the same clinician from the center of the distracted area, without knowing to which group the subjects belonged. The bone mineral density (BMD) and bone mineral content (BMC) values were determined using the small subject program (Figure 3B).

\section{Stereological analysis}

The preparations and stereological examinations of the tissue specimens were conducted blindly by a histologist. Soft tissues on the jaws were removed and decalcified for 21 days in formic acid (5\%). After the decalcification, the tissues were fixed with formaldehyde (10\%) and dehydrated gradually with alcohol. After dehydration, the samples were buried in fresh paraffin. About $7 \mu \mathrm{m}$-thick serial sections were obtained from each paraffin block with microtomes (Leica RM 2135; Leica Instruments, Nussloch, Germany). According to systematic random sampling manner, the paraffin blocks obtained from the samples taken from each jaw were sampled at a rate of 1/10. The first section was selected randomly. The selected sections were stained with hematoxylin-eosin and photographed with a color digital camera (Microbrightfield, Williston, VT, USA) using a light microscope (Leica M 4000 B, Germany) in a stereology analysis system (Stereoinvestigator 9.0, Microbrightfield, Williston, VT, USA). The Cavalieri method was applied to the light microscopy images to stereologically evaluate new bone, connective tissue, and neovascularization volumes. Point counting test grids were used to designate areas in sections (Figure 3A). Gundersen and Jensen's formula was applied to determine the point density. The coefficient of error and the coefficient of variation were determined with this formula (18). This grid was randomly positioned on the computer screen. The volume of the distraction area in all the mandibular incisions was determined by the following formula: Volume $=\mathrm{t} x \mathrm{a} / \mathrm{p} \mathrm{x}$ $\sum p$ where $t$ is the section thickness; $a / p$ is the area representing each point on the point counting table; and $\Sigma p$ the total number of points corresponding to the distraction area) (18).

\section{Statistical analysis}

The data obtained from the densitometric and stereological evaluations were compared with the one-way ANOVA test by loading it on the SPSS (version 13.0, IL, USA) statistical program in a computer environment. The comparisons between the groups were performed using the one-way analysis of variance (ANOVA) followed by the post-hoc
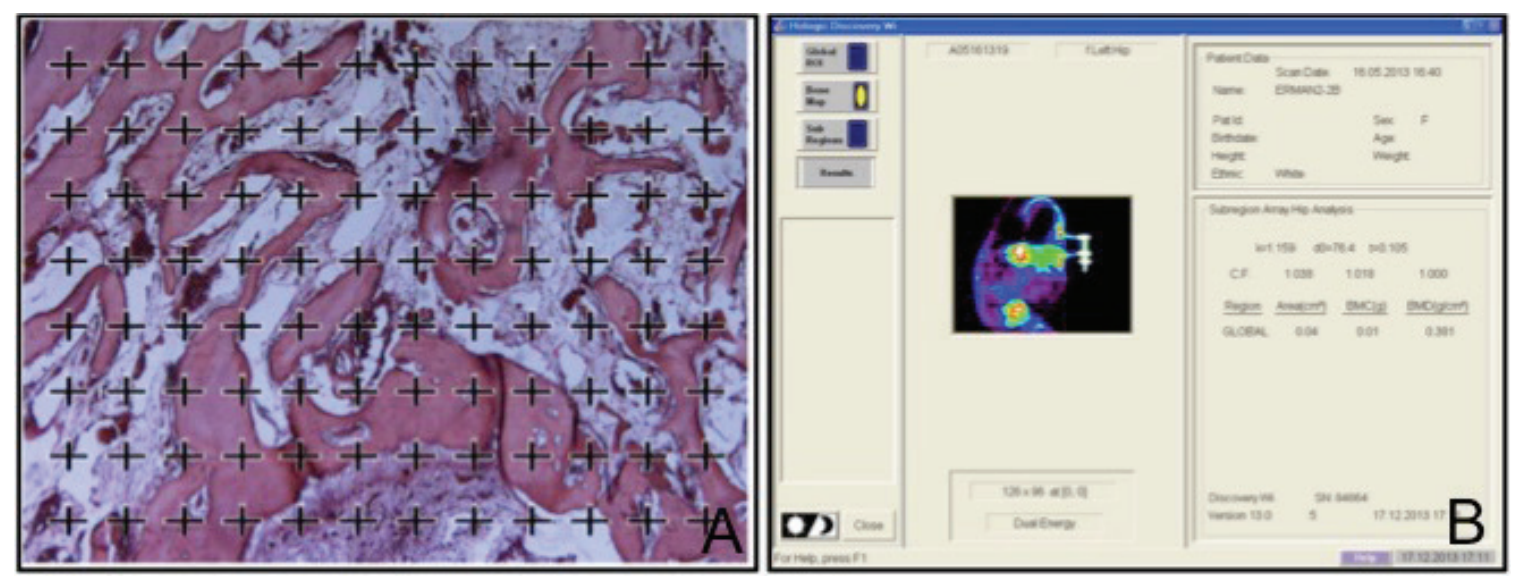

Figure 3. A. Measurement of tissue volume with point count grid in light microscope images using Cavalieri method. B. The software used for DEXA measurements. 
Tukey's HSD test. $p$ values smaller than 0.05 were considered statistically significant.

\section{Results}

\section{Clinical Observations and Animal Condition}

One rabbit in group A died in the experimental process because of infection and excessive weight loss. One rabbit in the control group was excluded from the experiment because of the unstable distractor. The remaining animals tolerated the osteotomy and distraction protocols. The distractor remained stable until the end of the experiment. After the DO application, all of the rabbits were observed to have a unilateral crossbite and an extensively lengthened incisor. The high resolution computed tomography (CT) images showed that the new bone formation in the distraction area was healthy in all groups (Figure 4).

\section{$B M D$ and $B M C$}

The BMD and BMC values were determined at the end of the first and fourth weeks of the consolidation period in all animals (Table 1). The highest BMD value was found in the control

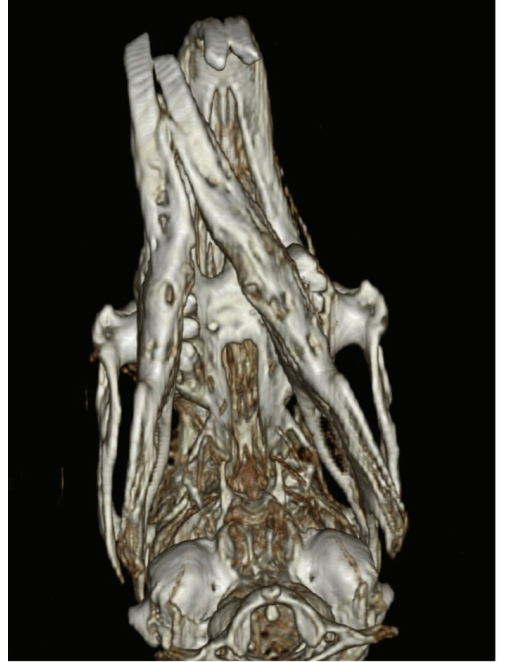

Figure 4. Three-dimensional (CT) image showing unilateral cross-bite and incisor elongation.

group according to the measurements made at the end of the first week, followed by the A group and the AB group. In the analysis made at the end of the fourth week, the measurement values similar to those of the first week were found. No

Table 1. BMD and BMC data obtained from DEXA examinations at $1^{\text {st }}$ and $4^{\text {th }}$ week of consolidation (mean \pm standard deviation, BMD: Bone mineral density, BMC: Bone mineral content)

\begin{tabular}{llcc} 
& & Control & AB \\
First Week & BMD $\left(\mathbf{g} / \mathbf{c m}^{2}\right)$ & $0.69 \pm 0.09$ & $0.62 \pm 0.10$ \\
\cline { 2 - 4 } Fourth Week & BMC $(\mathbf{g})$ & $0.022 \pm 0.011$ & $0.025 \pm 0.005$ \\
\hline & BMD $\left(\mathbf{g} / \mathbf{c m}^{2}\right)$ & $0.76 \pm 0.04$ & $0.022 \pm 0.008$ \\
\cline { 2 - 4 } & BMC $(\mathbf{g})$ & $0.030 \pm 0.000$ & $0.64 \pm 0.04$ \\
\hline
\end{tabular}
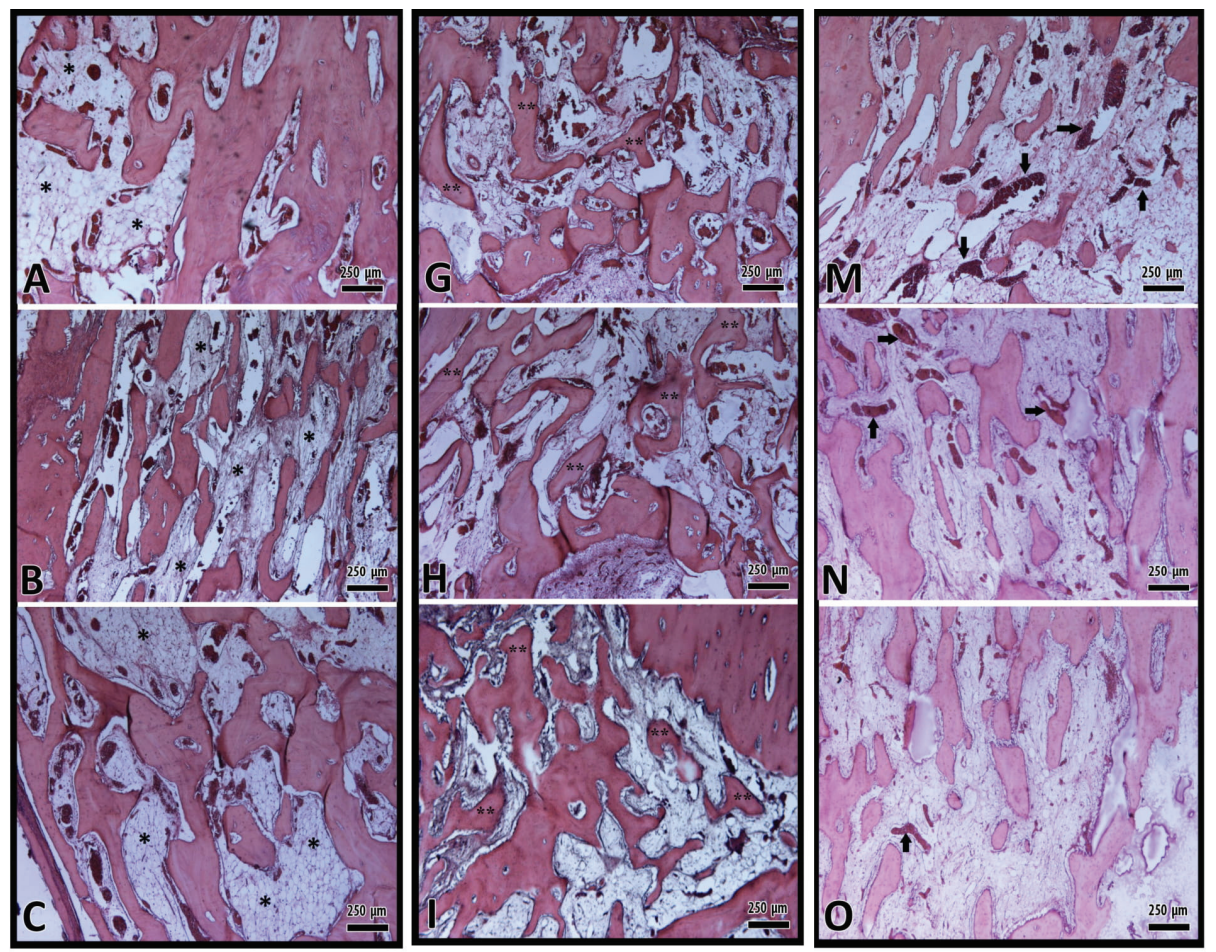

Figure 5. Histological image showing connective tissue areas of $A$ (Control), $B$ (Group $A$ ) and $C$ (Group AB). The connective tissue areas are marked with (*). New bone areas have been shown in $G$ (Control), $H$ (Group A) and I (Group AB) images. New bone areas are marked with (**). New vessel areas have been shown in $M$ (Control), $N$ (Group $A$ ) and $O$ (Group $A B$ ) images. New vessel areas are marked with black arrow. (original magnification $x 5$, hematoxylin-eosin). 
significant difference was found in the BMD results. Regarding $B M C$ results, the highest value was seen in group $A$ at the end of the first week and in the control group at the end of the fourth week. No statistically significant difference was found in the $B M C$ results. Although the BMD and BMC values increased at the end of the fourth week in comparison with those in the first week, this increase was not statistically significant.

\section{Tissue volumes}

As shown in the stereological examination, new bone tissue, connective tissue, and neovascularization volumes were detected in the animals that were sacrificed after the completion of distraction (Figure 5). In comparing the volume of new bone tissue, the highest value was found in the $A B$ group, and the difference was not statistically significant. The lowest new bone volume was observed in the control group. As shown in the results of the connective tissue volumes, the highest volumes were found was in the $A B$ group, followed by the A group and the control group. The differences between the groups were not found to be statistically significant. When the neovascularization volumes of the groups were evaluated, the highest value was found in the control group, and the differences between control and $A B$ and between control and A were statistically significant (Table 2).

Table 2. Tissue volumes obtained from the stereological examination (mean \pm standard deviation, different superscript letters indicate significant difference).

\begin{tabular}{cccc} 
& Control & A & AB \\
\hline New Bone & $0.20 \pm 0.02$ & $0.22 \pm 0.04$ & $0.24 \pm 0.04$ \\
\hline Connective Tissue & $0.35 \pm 0.02$ & $0.39 \pm 0.04$ & $0.41 \pm 0.11$ \\
\hline Neovascularization & $0.10 \pm 0.02^{\mathrm{a}}$ & $0.07 \pm 0.01^{\mathrm{ab}}$ & $0.07 \pm 0.01^{\mathrm{ab}}$ \\
\hline
\end{tabular}

\section{Discussion}

The acceleration of callus maturation, the improvement of the biomechanical properties, and the shortening of the consolidation period in DO have attracted the attention of researchers (17). Using a biostimulatory method that generates signals for the release of growth factors rather than only applying the growth factors in the distraction gap may have a greater strategic advantage (3).

ESWT may shorten the total treatment period by accelerating the callus maturation. In experimental animal models in the literature, ESWT has been reported to increase cell differentiation and neovascularization, thus accelerating the healing of fractures and increasing the amount of callus and cortical bone formation $(16,19)$. In addition, it has been shown to release more osteogenic and angiogenic growth factors, such as VEGF, endothelial nitric oxide synthase, proliferating cell nuclear antigen, and BMP-2 (16). ESWT has been shown to improve bone regeneration when applied with suitable parameters. However, the appropriate parameters for the induction of bone healing have not yet been determined. Not enough studies have been conducted to investigate the different parameters of the effect of ESWT on new bone formation in DO.
The effects of ESWT on DO were examined in two studies: the efficacy of two different energy flow densities in (17) and the effect of different numbers of impulses in (12). In both studies, ESWT was applied at the beginning of the consolidation period. Only Önger et al. (12) performed a second session on the fourth day of the consolidation. Whereas Lai et al. (17) reported that a 500 pulse shock wave therapy with an energy flow density of $0.19 \mathrm{~mJ} / \mathrm{mm} 2$ is effective in increasing angiogenesis and bone regeneration and in shortening the consolidation process, Önger et al.(12) showed that a 1,000 x2 pulse shock wave therapy at an energy flux density of $0.19 \mathrm{~mJ} /$ $\mathrm{mm}^{2}$ resulted in a higher new bone volume and bone mineral density. Lai et al. (17) also found that shock waves applied at $21 \mathrm{kV}$ and 500 pulses caused necrotic changes. In our study, the parameters reported to have a positive effect on ESWT in distraction were used, and obtaining more effective results would be possible by performing these applications both preoperatively and repeatedly.

Biostimulatory methods are effective in the angiogenesis and proliferative phases of wound healing because cell proliferation and differentiation, as well as the growth factor release, are at their highest during these periods (20). However, ESWT has also been shown to improve cortical and cancellous bone volume and to improve the mechanical properties of the bone in areas that do not undergo surgical procedures. ESWT shows this effect by generating transient bone marrow damage resulting in an anabolic process (21). Moreover, the preoperative application of ESWT to bone sites induces the proliferation of periosteum cambium cells and increases periosteal thickness (22). Thus, ESWT was performed before and after osteotomy in our study. The lack of difference between the $A B$ group and the control group in terms of new bone volume can be due to the stimulation conducted in three sessions, the number of shock waves, or the energy flux density.

DEXA is an important diagnostic method widely used to determine bone mineral density and to predict fracture risk $(17,23)$. The $B M D$ and $B M C$ values of each rabbit were measured using the DEXA method at the end of the first week (early period) and the fourth week (late period) of the consolidation period in our study. No statistically significant difference was found between the pre- and post-distraction applications of ESWT (Group $A B$ ) and the post-distraction application (Group A). Therefore, ESWT be sufficiently applied after distraction. Furthermore, the DEXA values in the experimental groups were lower than the values in the control group in the early and late periods. This finding may be due to the use of unfocused applicators (24). The different results obtained from those of Lai and Önger et al. may be due to the increase in the number of sessions, as one or two sessions of treatment were reported to result in higher BMD intensity in the control groups $(12,17)$.

The Cavalieri method in stereology is an effective and easily applied method used to calculate the volume of a tissue or organ. As it enables a three-dimensional evaluation, it reflects the tissue features better than histological evaluations and gives more realistic values (25). In this study, no statistically significant difference was found between the experimental groups and the control group in terms of new bone volume values. These results indicate that the ESWT applied in these parameters is not positively affected. The results of the 
stereological examination are consistent with those obtained with DEXA. A temporal and spatial relationship was found between angiogenesis and new bone formation throughout the distraction process (3). The lack of an increase in new bone tissue may be due to the fact that angiogenesis is not induced by ESWT, which provides adequate blood support. In the control group, the neovascularization was found to be significantly higher than that in the experimental groups. Studies in which ESWT induced bone healing reported an increased VEGF and thus neovascularization $(16,26)$. Nonetheless, Özkan et al. reported that unfocused ESWT did not have a positive effect on neovascularization and on the new bone formation in mandibular defect healing (27).

No study has yet examined the efficacy of pre-op applications of ESWT at DO. The answer to the question of what biostimulant method will work best in what phase of distraction is uncertain. However, most researchers reported that biostimulatory methods should be applied during early consolidation (28). The reason for ineffectiveness may be the early application of the ESWT during the healing process. Whereas cartilage tissue is intensely seen in the early stages of distraction, new bone tissue occurs during the consolidation process (29). Freddo et al. reported that the biostimulant method applied during the maturation period caused a further increase in bone hardness and elastic modulus values (30). The other reason for this contradiction between the results of this study and those of other studies may be that ESWT is also applied in the further stages of the consolidation phase of this study. Mature bone may cause more of the shock wave energy to be reflected from the soft-hard tissue boundaries in the later stages of consolidation. Therefore, the stimulation effect of the shock wave will be less in the later stages of consolidation (1).

\section{Conclusion}

The ESWT application had no positive effects on the bone maturation during the consolidation phase of DO procedure performed in rats, when applied before osteotomy or both before and after the osteotomy.

Türkçe Öz: Distraksiyon ssteogenezisi cerrahisinden önce uygulanan odaklanmamış ekstrakorporal şok dalga tedavisinin yeni kemik oluşumuna etkisinin değerlendirilmesi. Amaç: Bu çalışmada osteotomi işleminden önce ve/veya osteotomiden hemen sonra uygulanan ekstrakorporal şok dalga tedavisinin (ESWT) konsolidasyon fazında gözlenen kemik maturasyonuna olan etkisinin incelenmesi amaçlanmıştır. Gereç ve Yöntem: Çalışmada 21 adet dişi New Zealand cinsi tavşan kullanılmıştır. Denekler rastgele olarak 3 gruba ayrılmıştır: Kontrol (Yalnızca Distraksiyon), A Grubu (Osteotomiden sonra ESWT uygulanan), AB (Osteotomiden önce ve sonra ESWT uygulananlar). AB grubuna osteotomiden 5, 12 ve 19 gün sonra ve osteotomiden 7, 14 ve 21 gün önce, A grubuna ise yalnızca osteotomiden 5, 12 ve 19 gün sonra ESWT (500 atım, $5 \mathrm{~Hz}, 0.19 \mathrm{~mJ} / \mathrm{mm}^{2}$ enerji akış yoğunluğu) uygulaması yapıldı. Konsolidasyon fazının 28. gününde tüm denekler sakrifiye edildi. Kemik mineral içeriğinin ve kemik mineral yoğunluğunun tespit edilmesi amacıyla Dual-energy $x$-ray absorptiometry (DEXA) kullanıldı. Ayrıca yeni kemik dokusu, bağ dokusu ve yeni damar hacimlerinin tespit edilmesi amacıyla stereolojik methotlar kullanıldı. Bulgular: DEXA incelemesi sonuçlarına göre konsolidasyonun 1. ve 4. haftasında gruplar arasında kemik mineral yoğunluğu ve kemik mineral içeriği açısından anlamlı bir fark görülmemiştir. Stereolojik inceleme sonuçlarına göre ise $A B$ grubunda $A$ grubuna göre, $A B$ ve A grubunda ise kontrol grubuna göre daha yüksek oranda bağ dokusu ve yeni kemik dokusu hacmi görülmüştür. Ancak sonuçlar istatistik olarak anlamlı farklılık göstermemiştir. Yeni damar hacmi açısından ise bir farklılık görülmemiştir. Sonuç: Bu parametreler ile osteotomiden önce ve/veya osteotomiden sonra uygulanan ESWT, konsolidasyon fazında gözlenen kemik matürasyonunda pozitif etkili değildir. Anahtar Kelimeler: Kemik rejenerasyonu; distraksiyon osteogenezisi; dual enerji $x$-ray absorbsiyometri; ekstrakorporal şok dalga tedavisi; doku hacmi.

Ethics Committee Approval: This study received ethical approval with the number 2011/65 from the Animal Experiments Local Ethics Committee of OnDokuz Mayıs University.

Informed Consent: Not required.

Peer-review: Externally peer-reviewed.

Author contributions: ES and MCB designed the study. ES and EO participated in generating the data and gathering the data for the study. MCB and MEO participated in the analysis of the data. EO wrote the majority of the original draft of the paper and participated in writing the paper. All authors approved the final version of this paper.

Conflict of Interest: The author had no conflict of interest to declare.

Financial Disclosure: This study was supported by Project Management Office Coordinatorship of Ondokuz Mayıs University with PYO. DIS.1904.12.007 project code.

Acknowledgments: We would like to thank the staff of Nuclear Medicine Department of Ondokuz Mayıs University, Faculty of Medicine for DEXA imaging.

\section{References}

1. Raza H, Saltaji H, Kaur H, Flores-Mir C, El-Bialy T. Effect of LowIntensity Pulsed Ultrasound on Distraction Osteogenesis Treatment Time: A Meta-analysis of Randomized Clinical Trials. J Ultrasound Med 2016;35(2):349-58. [CrossRef]

2. Zimmermann C, Thurmuller M, Troulis D, Perrott B, Rahn L, Kaban B. Histology of the porcine mandibular distraction wound. Int J Oral Maxillofac Surg 2005;34(4), 411-9. [CrossRef]

3. Jiang X, Zhang Y, Fan X, Deng X, Zhu Y, Li F. The effects of hypoxiainducible factor (HIF)-1a protein on bone regeneration during distraction osteogenesis: an animal study. Int J Oral Maxillofac Surg 2016;45(2):267-2. [CrossRef]

4. Freddo AL, Giongo CC, Ponzoni D, Corsetti A, Puricelli E. Influence of a Magnetic Field and Laser Therapy on the Quality of Mandibular Bone During Distraction Osteogenesis in Rabbits. J Oral Maxillofac Surg 2016;74(11):2287.e1-2287.e8. [CrossRef]

5. Williams PR, Smith NC, Cooke-Yarborough C, Little DG. Bisphosphonates and nephrocalcinosis in a rabbit leg lengthening model: a histological and therapeutic comparison. Pharmacol Toxicol 2001;89:149-52. [CrossRef]

6. Primrose AC, Broadfoot E, Diner PA, Molina F, Moos KF, Ayoub AF. Patients' responses to distraction osteogenesis: a multi-centre study. Int J Oral Maxillofac Surg 2005;34(3):238-42. [CrossRef]

7. Zhu S, Song D, Jiang $X$, Zhou H, Hu J. Combined effects of recombinant human BMP-2 and Nell-1 on bone regeneration in rapid distraction osteogenesis of rabbit tibia. Injury 2011;42(12):1467-73. [CrossRef]

8. Yonezawa $\mathrm{H}$, Harada $\mathrm{K}$, Ikebe $\mathrm{T}$, Shinohara $\mathrm{M}$, Enomoto $\mathrm{S}$. Effect of recombinant human bone morphogenetic protein-2 (rhBMP-2) on bone consolidation on distraction osteogenesis: a preliminary study in rabbit mandibles. J Craniomaxillofac Surg 2006;34(5):270-6. [CrossRef]

9. Castro-Govea $\mathrm{Y}$, Cervantes-Kardasch VH, Borrego-Soto G, Martínez-Rodríguez HG, Espinoza-Juarez M, Romero-Díaz V, Marino-Martínez IA, Robles-Zamora A, Álvarez-Lozano E, PadillaRivas GR, Ortiz-López R, Lara-Arias J, Vázquez-Juárez J, Rojas- 
Martínez A. Human bone morphogenetic protein 2-transduced mesenchymal stem cells improve bone regeneration in a model of mandible distraction surgery. J Craniofac Surg 2012;23(2):3926. [CrossRef]

10. Alp YE, Taskaldiran A, Onder ME, Karahan S, Kocyigit ID, Atil F, Tekin U. Effects of Local Low-Dose Alendronate Injections Into the Distraction Gap on New Bone Formation and Distraction Rate on Distraction Osteogenesis. J Craniofac Surg 2017;28(8):21748. [CrossRef]

11. Taylor BA, Bezuhly M, Brace M, Carter M, Hong P. Effect of strontium citrate on bone consolidation during mandibular distraction osteogenesis. Laryngoscope 2017;127(7):e212-8. [CrossRef]

12. Onger ME, Bereket C, Sener I, Ozkan N, Senel E, Polat AV. Is it possible to change of the duration of consolidation period in the distraction osteogenesis with the repetition of extracorporeal shock waves? Med Oral Patol Oral Cir Bucal 2017;22(2):e251-7. [CrossRef]

13. Martini L, Giavaresi G, Fini M, Torricelli P, de Pretto $M$, Schaden W, Giardino R. Effect of extracorporeal shock wave therapy on osteoblastlike cells. Clin Orthop Relat Res 2003;413:269-80. [CrossRef]

14. Huang HM, Li XL, Tu SQ, Chen XF, Lu CC, Jiang LH. Effects of roughly focused extracorporeal shock waves therapy on the expressions of bone morphogenetic protein- 2 and osteoprotegerin in osteoporotic fracture in rats. Chin Med J (Engl) 2016;129(21):2567-75. [CrossRef]

15. Wang FS, Yang KD, Kuo YR, Wang CJ, Sheen-Chen SM, Huang HC, Chen YJ.Temporal and spatial expression of bone morphogenetic proteins in extracorporeal shock wave-promoted healing of segmental defect. Bone 2003;32:387-96. [CrossRef]

16. Wang CJ, Wang FS, Yang KD. Biological Effects of Extracorporeal Shockwave in Bone Healing: A Study in Rabbits, Arch Orthop Trauma Surg 2008;128:879-84. [CrossRef]

17. Lai JP, Wang FS, Hung CM, Wang CJ, Huang CJ, Kuo YR. Extracorporeal shock wave accelerates consolidation in distraction osteogenesis of the rat mandible. J Trauma 2010;69(5):1252-8. [CrossRef]

18. Şahin B, Emirzeoglu M, Uzun A, İncesu L, Bek Y, Bilgiç S, Kaplan $S$. Unbiased estimation of the liver volume by the Cavalieri principle using magnetic resonance images. Eur J Radiol 2003;47:164-70. [CrossRef]

19. Bulut O, Eroglu M, Ozturk H, Tezeren G, Bulut S, Koptagel E. Extracorporeal shock wave treatment for defective nonunion of the radius: a rabbit model. J Orthop Surg 2006;14(2):133-7. [CrossRef]
20. Potres Z, Deshpande S, Klöeppel H, Voss K, Klineberg I. Assisted wound healing and vertical bone regeneration with simultaneous implant placement: a histologic pilot study. Int J Oral Maxillofac Implants 2016;31(1):45-54. [CrossRef]

21. van der Jagt OP, Piscaer TM, Schaden W, Li J, Kops N, Jahr H, van der Linden JC, Waarsing JH, Verhaar JA, de Jong $M$, Weinans $H$. Unfocused extracorporeal shock waves induce anabolic effects in rat bone. J Bone Joint Surg Am 2011;93(1):38-48. [CrossRef]

22. Kearney CJ, Hsu HP, Spector M. The use of extracorporeal shock wave-stimulated periosteal cells for orthotopic bone generation. Tissue Eng Part A 2012;18(13-14):1500-8. [CrossRef]

23. Ma D, Ren L, Yao H, Tian W, Chen F, Zhang J, Liu Y, Mao T. Locally injection of cell sheet fragments enhances new bone formation in mandibular distraction osteogenesis: a rabbit model. J Orthop Res 2013;31(7):1082-8. [CrossRef]

24. van der Jagt OP, van der Linden JC, Schaden W, van Schie HT, Piscaer TM, Verhaar JA, Weinans $\mathrm{H}$, Waarsing JH. Unfocused extracorporeal shock wave therapy as potential treatment for osteoporosis. J Orthop Res 2009;27(11):1528-33. [CrossRef]

25. Çakir-Özkan N, Bereket C, Arici N, Elmali M, Şener I, Bekar E. The radiological and stereological analysis of the effect of low-level laser therapy on the mandibular midline distraction osteogenesis. J Craniofac Surg 2015;26(7):e595-9. [CrossRef]

26. Wang FS, Yang KD, Wang CJ, Huang HC, Chio CC, Hsu TY, Ou CY. Shockwave stimulates oxygen radical-mediated osteogenesis of the mesenchymal cells from human umbilical cord blood. J Bone Miner Res 2004;19(6):973-82. [CrossRef]

27. Özkan E, Bereket MC,Önger ME, Polat AV.The Effect of Unfocused Extracorporeal Shock Wave Therapy on Bone Defect Healing in Diabetics. J Craniofac Surg 2018;29(4):1081-6. [CrossRef]

28. Ding Y, Li G, Ao J, Zhou L, Ma Q, Liu Y. 99mTechnetium-methylene diphosphonate bone imaging using low-intensity pulsed ultrasound: promotion of bone formation during mandibular distraction osteogenesis in dogs. Br J Oral Maxillofac Surg 2010;48:94-9. [CrossRef]

29. Cerqueira A, Silveira RL, Oliveira MG, Sant'ana Filho M, Heitz C. Bone tissue microscopic findings related to the use of diode laser $(830 \mathrm{~nm})$ in ovine mandible submitted to distraction osteogenesis. Acta Cir Bras 2007;22(2):92-7. [CrossRef]

30. Freddo AL, Hübler $R$, de Castro-Beck $C A$, Heitz $C$, de Oliveira MG. A preliminary study of hardness and modulus of elasticity in sheep mandibles submitted to distraction osteogenesis and low-level laser therapy. Med Oral Patol Oral Cir Bucal 2012;17(1):e102-7. [CrossRef] 